\title{
NIKAH SIRRI DALAM PERSPEKTIF ISLAM, KRISTEN DAN HUKUM POSITIF INDONESIA
}

\author{
Abdullah Jawawi \\ Institut Parahikma Indonesia (IPI) Gowa \\ e-mail: abdullahjawawi85@gmail.com
}

\begin{abstract}
Abstrak
تناقش هذه الورقة "الزواج السري في وجهة نظر الإسلام والمسيحية والقانون

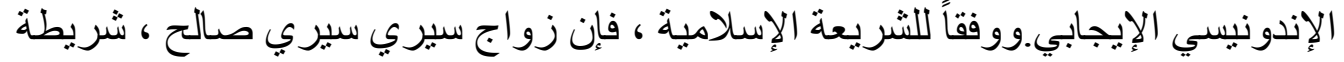

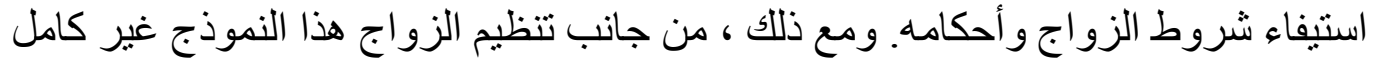

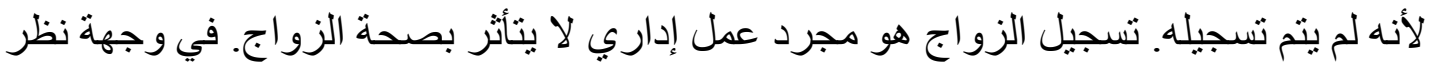

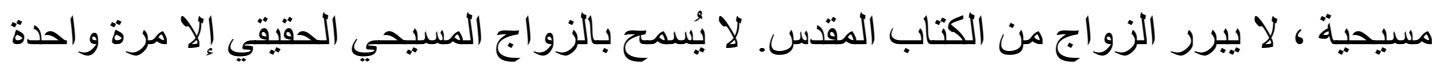

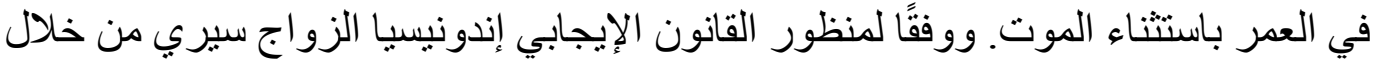

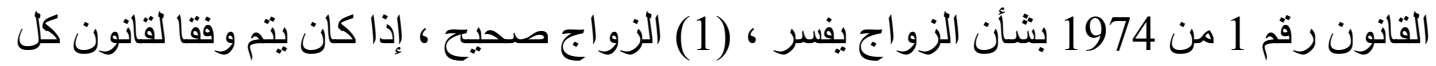
. دين ومعتقد ؛ (2) يتم تسجيل كل زو اج وفقا للقق انين و اللو ائح السائدة.
\end{abstract}

Kata Kunci : Nikah Sirri, Perspektif Islam, Kristen, Hukum Positif Indonesia.

\section{Pendahuluan}

Perkawinan adalah suatu akad yang suci dan luhur antara laki-laki dan perempuan sebagai suami istri yang sah dan dihalalkannya hubungan seksual dengan tujuan mencapai keluarga sakinah, mawaddah wa rahmah, penuh kebijakan dan saling menyantuni. ${ }^{1}$ Islam menganjurkan adanya sebuah perkawinan. Karena ia mempunyai pengaruh yang baik bagi pelakunya sendiri, masyarakat dan seluruh umat manusia. Suatu perkawinan akan lahir daripadanya ikatan yang menghalalkan hubungan kelamin antara laki-laki dan perempuan sebagai suami isteri yang bertujuan membentuk keluarga bahagia yang kekal berdasarkan Ketuhanan Yang Maha Esa.

Perkawinan dapat dikatakan sebagai suatu perjanjian pertalian antara lakilaki dan perempuan yang berisi persetujuan hubungan dengan maksud menyelenggarakan kehidupan secara bersama-sama menurut syarat-syarat dan

\footnotetext{
${ }^{1}$ Sudarsono, Pokok-Pokok Hukum Islam, (Cet.1; Jakarta: Rineka Cipta, 1992), h.188.
} 
hukum susila. Di mata orang yang memeluk agama, pengesahan hubungan perkawinan diukur dengan ketentuan-ketentuan yang telah ditentukan Tuhan sebagai syarat mutlaq dan bagi orang-orang yang tidak mendasarkan perkawinan pada hukum ilahi, perkawinan dalam teori dan praktiknya adalah merupakan suatu kontrak sosial yang berisi persetujuan bahwa mereka akan hidup sebagai suami istri dan persetujuan tersebut diakui undang-undang atauadat dalam suatu masyarakat tersebut. ${ }^{2}$ Dengan perkawinan dapat membuat anak-anak menjadi mulia, memperbanyak keturunan, melestarikan hidup manusia serta memelihara nasab. Islam dalam menganjurkan perkawinan menggunakan beberapa cara. Sesekali disebutnya sebagai salah satu sunnah para nabi dan petunjuknya, yang mana mereka itu merupakan tokoh-tokoh tauladan yang wajib diikuti jejaknya. Firman Allah swt dalam QS.Ar-Ra'ad:38 yang artinya;

"Dan sesungguhnya Kami telah mengutus beberapa Rasul sebelum kamu dan

Kami memberikan kepada mereka isteri-isteri dan keturunan. Dan tidak ada

hak bagi seorang Rasul mendatangkan sesuatu ayat (mu jizat) melainkan dengan izin Allah. Bagi tiap-tiap masa ada Kitab (yang tertentu)". 3

Akhir-akhir ini, fenomena nikah siri memberikan kesan yang menarik. Pertama, nikah siri sepertinya memang benar-benar telah menjadi trend yang tidak saja dipraktekkan oleh masyarakat umum, namun juga dipraktekkan oleh figur masyarakat yang selama ini sering disebut dengan istilah kyai, dai, ustad, ulama, atau istilah lainnya yang menandai kemampuan seseorang mendalami agama (Islam). Kedua, nikah siri sering ditempatkan menjadi sebuah pilihan ketika seseorang hendak berpoligami dengan sejumlah alasannya tersendiri.

Penyebab yang menimbulkan masyarakat melakukan pernikahan siri sebenarnya kembali kepada pribadinya masing-masing. Namun yang terjadi belakangan ini hal-hal yang menyebabkan timbulnya nikah dilihat dari faktor sosial dikarenakan adanya kesulitan pencatatan pernikahan yang kedua kalinya, batasan usia yang layak nikah berdasarkan peraturan perundang-undangan, tempat tinggal yang berpindah-pindah membuat orang kesulitan untuk mengurus administrasi dan prosedur pencatatan pernikahan. Kemudian ada faktor ekonomi dimana masyarakat yang kurang mampu biasanya akan kesulitan untuk membayar biaya-biaya untuk mencatatkan pernikahannya sehingga lebih memilih nikah siri. Selanjutnya ada juga faktor agama dimana nikah siri dilakukan untuk menghalalkan suatu hubungan agar dijauhkan dari zinah dan dosa.

Beberapa peristiwa menunjukkan bahwasanya akad nikah sebagai ikatan kekeluargaan yang fundamental perlu dijaga dan diselamatkan. Sebab, terkadang

${ }^{2}$ Nasarudin Latif, Ilmu Perkawinan : Problematika Seputar Keluarga dan Rumah Tangga, (Cet.1; Jakarta: Pustaka Hidayah, 2001), h.13-14.

${ }^{3}$ Departemen Agama RI, Al-Qur"an al-Karim dan Terjemahnya, (Semarang : CV. Toha Putra, 1996), h.376. 
terjadi dua orang pria dan perempuan mengaku sebagai suami isteri tanpa surat kawin kemudian salah satu pihak merasa telah lepas dari ikatan perkawinan sedang pihak lainnya membantah pula di depan pengadilan. Adapula sementara orang yang mengakui telah kawin dengan seorang perempuan dengan berdusta dan maksudnya untuk popularitas, atau untuk tujuan tertentu dengan cara gampang, karena fiqh memang dapat membenarkan dengan kesaksian umum atau saksi Sama'i dalam perkawinan. Karena itu, orang memerlukan surat kawin untuk menghormati akad ini dan untuk menjaga kemungkinan adanya pelanggaran-pelanggaran atau sangkalan dan juga untuk menghindari kerusakan-kerusakan yang mungkin timbul. ${ }^{4}$

\section{Pembahasan}

Pernikahan siri lazim disebut pernikahan di bawah tangan.Pernikahan siri dilakukan di hadapan ustaz atau ulama, namun tidak dicatat di Kantor Urusan Agama (Pegawai Pencatat Pernikahan). Secara agama, perkawinan tersebut sah, namun secara hukum, perkawinan ini tidak diakui resmi oleh negara.Dengan demikian, hak perempuan sebagai istri lemah secara hukum, apalagi jika status calon suami yang masih terikat perkawinan.

Secara harfiah "sirri" itu artinya "rahasia". Jadi, nikah sirri adalah pernikahan yang dirahasiakan dari pengetahuan orang banyak.Secara umum Nikah Siri adalah sebuah perbuatan dalam melakukan pernihakan sesuai aturan agama dalam hal ini Ajaran Islam namun karena berbagai hal yang menghalanginya menjadikan tidak terjadinya pencatatan secara sah atau legal oleh aparat yang berwenang dalam hal ini Pemerintah yang diwakili Departemen Agama. Nikah siri dalam konteks masyarakat sering dimaksudkan dalam beberapa pengertian sebagai berikut :

Pertama : nikah yang dilaksanakan dengan sembunyi-sembunyi, tanpa mengundang orang luar selain dari kedua keluarga mempelai. Kemudian tidak mendaftarkan perkawinannya kepada Kantor Urusan Agama (KUA) sehingga nikah mereka tidak mempunyai legalitas formal dalam hukum positif di Indonesia sebagaimana yang diatur dalam undang-undang perkawinan.Banyak faktor yang menyebabkan seseorang tidak mencatatkan pernikahannya di lembaga pencatatan sipil negara. Ada yang karena faktor biaya, alias tidak mampu membayar administrasi pencatatan, ada pula yang disebabkan karena takut ketahuan melanggar aturan yang melarang pegawai negeri nikah lebih dari satu, dan lain sebagainya.

Kedua :nikah yang dilakukan sembunyi-sembunyi oleh sepasang lakiperempuan tanpa diketahui oleh kedua pihak keluarganya

\footnotetext{
${ }^{4}$ H.S.A Al Hamdani, Risalah Nikah, Hukum Perkawinan Islam, (Jakarta :Pustaka Amani,
} 2002), h. 80 . 
sekalipun. Bahkan benar-benar dirahasiakan sampai tidak diketahui siapa yang menjadi wali dan saksinya.

Ketiga :pernikahan yang dirahasiakan karena pertimbangan-pertimbangan tertentu, misalnya karena takut mendapatkan stigma negatif dari masyarakat yang terlanjur menganggap tabu pernikahan siri, atau karena pertimbangan-pertimbangan rumit yang memaksa seseorang untuk merahasiakan pernikahannya. ${ }^{5}$

Fenomena pernikahan siri ini bukanlah suatu permasalahan yang baru-baru ini terjadi di tengah-tengah masyarakat tetapi merupakan suatu permasalahan yang sudah hangat dan merebak khususnya di Indonesia. Pernikahan siri dipandang sebuah permasalahan yang melanggar norma kemanusiaan dan agama padahal mempelajari norma hukum atau norma agama berarti mempelajari pengaruh hukum terhadap masyarakat. Dapat kita lihat dari beberapa permasalahan-permasalahan yang sekarang ini heboh dibicarakan di kalangan masyarakat.

Kehidupan bersuami istri yang dibangun melalui lembaga perkawinan, sesungguhnya bukanlah semanta-mata dalam rangka penyaluran hasrat biologis.Maksud dan tujuan nikah jauh lebih luas dibandingkan sekedar hubungan seksual.Bahkan apibila dipandang dari aspek religius, pada hakekatnya nikah adalah salah satu bentuk pengabdian kepada Allah. Karena itu, nikah yang sarat nilai dan bertujuan untuk mewujudkan kehidupan rumah tangga yang sakinahmawaddah wa rahmah, perlu diatur dengan syarat dan rukun tertentu agar tujuan disyariatkannya nikah tercapai. Rukun dan syarat menentukan suatu perbuatan hukum, terutama yang menyangkut dengan sah atau tidaknya perbuatan tersebut dari segi hukum. Kedua kata tersebut mengandung arti yang sama dalam hal keduanya merupakan sesuatu yang harus diadakan. ${ }_{-}^{6}$

\section{Nikah Siri Dalam Perspektif Islam}

Nikah sirri atau nikah yang dirahasiakan memang sudah dikenal di kalangan para ulama. Hanya saja nikah sirri yang dikenal pada masa lampau berbeda definisinya dengan nikah sirri pada saat ini. Dahulu yang dimaksud dengan nikah sirri yakni pernikahan sesuai dengan rukun-rukun perkawinan dan syaratnya menurut syar'at, walaupun saksi diminta tidak memberitahukan terjadinya pernikahan tersebut kepada khalayak ramai, kepada masyarakat, dan dengan sendirinya tidak ada walimatul 'ursy. Nikah sirri yang dikenal oleh masyarakat Indonesia dewasa ini adalah pernikahan yang dilakukan oleh wali atau wakil wali dan disaksikan oleh para

${ }^{5}$ http://kampus.okezone.com/read/polemik-pernikahan-siri-perlindungan-hukum-bagiperempuan/Diaksespada 25 Oktober 2018.

${ }^{6}$ Amir Syarifuddin, Hukum Nikah Islam di Indonesia: Antara Fikih Munakahat dan UndangUndang Nikah (Cet. II; Jakarta: Kencana, 2007), h. 59. 
saksi, tetapi tidak dilakukan di hadapan Petugas Pencatat Nikah sebagai aparat resmi pemerintah atau tidak dicatatkan di Kantor Urusan Agama bagi yang beragama Islam atau di Kantor Catatan Sipil bagi yang tidak beragama Islam

Dalam Hukum Islam, hukum perkawinan merupakan salah satu aspek yang paling banyak diterapkan oleh kaum muslimin di seluruh dunia dibanding dengan hukum-hukum muamalah yang lain. ${ }^{7}$ Perkawinan adalah mitsaqan ghalidan, atau ikatan kokoh yang dianggap sah jika telah memenuhi syarat dan rukun pernikahan. Berdasarkan al-Qur'an dan hadis, para ulama menyatakan bahwa ha-hal yang termasuk rukun pernikahan adalah calon mempelai (laki-laki dan perempuan), wali, dua orang saksi, ijab dan qabul. Kewajiban harus adanya saksi adalah pendapat Imam Syafi'i, Hanafi dan Hanbali. ${ }^{8}$ Sedangkan syarat sahnya nikah, menurut Wahbah Zuhaili adalah tidak ada hubungan nasabantara suami Istri, sighat ijab qabul tidak terbatas waktu, adapersaksian, tanpa paksaan, ada kejelasan calon suami istri, tidak sedang ihram, ada mahar, tidak ada kesepakatan untuk menyembunyikan akad nikah salah satu calon mempelai tidak sedang menderita penyakit kronis, adanya wali. $^{9}$

Berdasarkan kriteria rukun maupun syarat nikah diatas, tidak ada tercantum tentang pencatatan. Keberadaan saksi sianggap telah memperkuat keabsahan suatu perkawinan. Pihak-pihak terkait tidak bisa mengadakan pengingkaran akan akad yang sudah terjadi. Biasa jadi ini didasarkan pada pernikahan masa Rasulullah saw.,sendiri tidak ada yang dicatatkan. Dalam kitab fikih klasikpun tidak ada pembahasan tentang pencatatan pernikahan. Berikut ini adalah pendapat para ulama Islam tentang nikah siri;

1. Menurut pandangan mahzab Hanafi dan Hambali suatu penikahan yang sarat dan rukunya mka sah menurut agama islam walaupun pernikah itu adalah pernikahn siri. Hal itu sesuai dengan dalil yang berbunyi, artinya: "Takutlah kamu terhadap wanita, kamu ambil mereka (dari orang tuanya) dengan amanah allah dan kamu halalkan percampuran kelamin dengan mereka dengan kalimat Allah (ijab qabul)" (HR Muslim).

2. Mazhab Maliki tidak membolehkan nikah siri. Perkawinannya dapat dibatalkan, dan kedua pelakunya dapat dilakukan hukuman had(dera

${ }^{7}$ J.N.D Anderson, Hukum Islam di Dunia Modern (Yogyakarta: Tiara Wacana, 1994), h.46.

${ }^{8}$ Mahmud Yunus, Hukum Perkawinan Dalam Islam Menurut Mazhab Syafi'I, Hanafi, Maliki dan Hanbali (Jakarta: Hidakarya Agung, 1996), h. 18.

${ }^{9}$ Wahbah Zuhaili, Al-Fiqh al-Islam wa adillatuhu (Beirut, Dar-al-Fikr, 1989), h. 62. 
rajam), jika telah terjadi hubungan seksual antara keduanya dan diakuinya atau dengan kesaksian empat orang saksi. ${ }^{10}$

3. Kyai Husein Muhamad seorang komisioner Komnas Perempuan menyatakan pernikahan pria dewasa dengan wanita secara siri merupakan pernikahan terlarang karena pernikahn tersebut dapat merugikan si perempauan, sedangkan dalam pernikahan Islam jusru melindungi perempuan bukan malah merugikannya.

4. Ulama terkemuka yang membolehkan nikah dengan cara siri adalah Dr. Yusuf Qardawi salah seorang pakar muslim kontemporer terkemuka di Islam. Ia berpendapat bahwa nikah siri itu sah selama ada ijab kabul dan saksi.

5. Dadang Hawari, mengharamkan nikah siri, sedangkan KH. Tochri Tohir berpendapat lain. Ia menilai nikah siri sah dan halal, karena islam tidak pernah mewajibkan sebuah nikah harus dicatatkan secara negara. Menurut Tohir, nikah siri harus dilihat dari sisi positifnya, yaitu upaya untuk menghindari Zina. Namun ia juga setuju dengan pernyataan Dadang Hawari bahwa saat ini memang ada upaya penyalahgunaan nikah siri hanya demi memuaskan hawa nafsu. Menurutnya, nikah siri semacam itu, tetap sah secara agama, namun perkawinannya menjadi tidak berkah.

6. Menurut Prof. Wasit Aulawi seorang pakar hukum Islam Indonesia, mantan Direktur Pembinaan Badan Peradilan Agama yang juga mantan Dekan Fakultas Syariah UIN Jakarta, menyatakan bahwa ajaran Islam, nikah tidak hanya merupakan hubungan perdata, tetapi lebih dari itu nikah harus dilihat dari berbagai aspek. Paling tidak menurutnya ada tiga aspek yang mendasari perkawinan, yaitu: agama, hukum dan sosial, nikah yang disyariatkan Islam mengandung ketiga aspek tersebut, sebab jika melihat dari satu aspek saja maka pincang.

7. Quraish Shihab mengemukakan bahwa betapa pentingnya pencatatan nikah yang ditetapkan melalui undang-undang di sisi lain nikah yang tidak tercatat-selama ada dua orang saksi-tetap dinilai sah oleh hukum agama, walaupun nikah tersebut dinilai sah, namun nikah dibawah tangan dapat mengakibatkan dosa bagi pelakunya, karena melanggar ketentuan yang ditetapkan oleh pemerintah. Al-Qur'an memerintahkan setiap muslim untuk taat pada ulul amri selama tidak bertentangan dengan hukum Allah. ${ }^{11}$ 1989), h. 71

${ }^{10}$ Wahbah al-Zuhaili, Fiqh al-Islam wa 'Adillatuh, Juz VIII (Cet. III; Beirut: Dar al-Fikr,

${ }^{11}$ Quraish Shihab, Wawasan al-Qur'an: Tafsir Maudhu'i Atas Perbagai Persoalan Umat (Cet. VIII; Jakarta: Mizan, 1998), h. 204. 
8. Majelis Ulama Indonesia (MUI) mengeluarkan fatwa tentang nikah di bawah tangan atau nikah siri dengan 2 (dua) ketentuan hukum, yakni. (1) Pernikahan di Bawah Tangan hukumnya sah karena telah terpenuhi syarat dan rukun nikah, tetapi haram jika terdapat dampak negatif (madharrah). (2) Pernikahan harus dicatatkan secara resmi pada instansi berwenang, sebagai langkah preventif untuk menolak hal-hal yang bersifat madharrah. ${ }^{12}$

Sepanjang dilaksanakan sesuai dengan ketentuan nikah dalam syariat Islam (ada wali, saksi, ijab qabul, dan mahar) nikahnya sah secara hukum Islam.Yang pertama tidak dicatat oleh petugas pencatat nikah, sah secara agama Islam, tidak sah menurut undang-undang yang berlaku di Negara Republik Indonesia.Kekurangan dari kedua pelaksanaan tersebut adalah tidak ada publikasi, tidak diumumkan secara meluas kepada masyarakat.Menurut ajaran Islam, nikah itu tidak boleh secara sembunyi-sembunyi, tetapi harus dipublikasikan agar warga, tetangga, handai taulan mengetahuinya.Nabi memberi pesan agar nikah itu dipublikasikan (diwalimahkan), dan disebarluaskan kepada keluarga dan tetangga.Bahkan Beliau menganjurkan agar melaksanakan walimah walaupun hanya memotong seekor kambing. Yang bisa diperoleh dari publikasi nikah itu adalah agar terhindar dari fitnah dan buruk sangka orang lain kepada yang bersangkutan, sekaligus menutup adanya kemungkinan yang bersangkutan (khususnya istri) diminati oleh orang lain. Walaupun demikian, mungkin dalam satu kasus nikah sirri itu dianggap perlu karena pertimbanganpertimbangan kemaslahatan bersama, baik dari pihak suami atau pihak istri.Artinya nikah sirri itu dilakukan dalam rangka penyelamatan yang bersangkutan dari kemungkinan sesuatu mudarat apabila nikah sirri itu cepat-cepat dipublikasikan.

\section{Nikah Siri Dalam Perspektif Kristen}

Pandangan Alkitab tentang pernikahan adalah komitmen seumur hidup antara seorang laki-laki sampai maut memisahkan dengan seorang perempuan yang melibatkan hak-hak seksual timbal balik.Sedikitnya ada 3 unsur dasar dalam konsep Al-kitab tentang pernikahan. ${ }^{13}$

1. Pernikahan adalah antara seorang laki-laki biologis dengan seorang perempuan biologis.

Hal ini jelas dari sejak mulanya.Allah menciptakan "laki-laki dan perempuan" dan memerintahkan mereka untuk beranakcucu dan bertambah banyak. (Kitab Kejadian 1:27 ayat 28)

2. Pernikahan melibatkan penyatuan seksual.

\footnotetext{
${ }^{12}$ Ma'ruf Amin, dkk. Himpunan Fatwa Mui Sejak 1975, (Jakarta: Erlangga, 2011), h. 534.

${ }^{13}$ Norman L. Geisler, "Etika Kristen Pilihan dan Isu”. (SAAT: Malang, 2010). h. 356.
} 
Sekalipun pernikahan melibatkan hak-hak seksual, pernikahan tidak terbatas pada seks saja.Pernikahan adalah suatu persahabatan, suatu penyatuan "perjanjian" yang jauh melebihi seks.Pernikahan adalah penyatuan sosial dan spiritualitas serta seksual.Selain itu, tujuan seks lebih dari sekedar perkembangbiakan.

3. Pernikahan melibatkan perjanjian di hadapan Allah.

Pernikahan juga penyatuan yang lahir dari perjanjian dari janji-janji yang timbal balik. Allah menjadi saksi akan janji pernikahan yang diikrarkan oleh pasangan suami-istri. Allah lah yang menetapkan pernihakan, dan Dia lah yang menyaksikan ikrarnya.Ikrar tersebut dibuat di hadapan Allah.

Hakikat pernikahan dalam Kristen adalah pernikahan yang berdasarkan pada prinsip-prinsip dan ketentuan-ketentuan yang ditetapkan Allah melalui firman-Nya. Hakikat itu adalah sebagai berikut: ${ }^{14}$

a. Allah Yang Menciptakannya

Pernikahan bukanlah temuan manusia. Ajaran Kristus tentang hal ini diawali dengan gagasan prakarsa Allah, bukan gagasan manusia. Pernikahan sudah ditetapkan Allah pada masa sebelum kejatuhan manusia dalam dosa. Pernikahan kemudian mendapat keindahan dan pamornya yang agung oleh kehadiran Kristus pada waktu turut merayakan pesta pernikahan di Kana; dan kemudian pernikahan melambangkan hubungan Kristus dengan jemaat-Nya. Dengan faktafakta tersebut maka pernikahan adalah Allah sendiri yang menciptakannya,Allah juga yang mengesahkannya dan Allah juga yang mengangkatnya ke tingkat yang paling mulia. ${ }^{15}$

b. Pernikahan adalah hubungan yang suci.

Pernikahan adalah institusi dan tata tertib suci yang ditetapkan Allah sebelum manusia jatuh ke dalam dosa. Dalam hubungan yang suci itu Allah mengatur hubungan pria dan wanita. Allah berfirman, "Sebab itu seorang laki-laki akan meninggalkan ayahnya dan ibunya dan bersatu dengan isterinya, sehingga keduanya menjadi satu daging." Ini merupakan pernyataan Allah yang menyangkut karakter dan tanggungjawab pernikahan.

c. Menggambarkan hubungan Kristus dengan umat-Nya.

Dalam Perjanjian Lama pewartaan para Nabi, menyampaikan dengan jelas dan kongkret berdasarkan pengalaman pelayanan sehari-hari. Pengalaman tentang pernikahan menjelaskan maksud tersebut. Yesaya

${ }^{14}$ J. Verkuil,“Etika Kristen Seksuil”. BPK: Jakarta, 1984, h. 54.

${ }^{15}$ John Stott,“Isu-Isu Global Menantang Kepemimpinan Kristiani”, (Trans. G.M.A. Nainggolan. YKBK:Jakarta, 2005). h. 368. 
mengungkapkan tentang kasih Allah kepada umat-Nya. Kiasan ini dipakai Allah untuk mengungkapkan hubungan antara Allah dan umat pilihan-Nya yang ditekankan pada kasih Tuhan.

d. Pernikahan sebagai peraturan monogami.

Di dalam Alkitab, pernikahan dipandang sebagai suatu peraturan monogami.Monogami dibela sebagai tuntutan Tuhan karena monogami sajalah yang sesuai dengan kasih yang melayani. Orang yang meninggalkan monogami dan menempuh jalan poligami mungkin merasa , bahwa jalan menuju kepada poligami itulah jalan kebahagiaan, melainkan sebenarnya jalan kehancuran. Monogami itu bukanlah sebuah tuntutan, tetapi juga suatu pemberian yang besar.

Nikah Siri dalam perspektif Kristen merupakan suatu pelanggaran moral dan hukum. Sesuai dengan hukum yang berlaku di Indonesia sendiri, pernikahan yang tidak tercatat di dalam Pencatatan Sipil merupakan sebuah pelanggaran.Dikatakan pelanggaran walaupun sudah sesuai dengan syarat hukum Islam karena pernikahan sirri ini tidak memiliki perlindungan hukum yang kuat oleh pemerintah.Jadi, apabila sesuatu hal yang tidak diinginkan terjadi setelah pernikahan sirri ini misalnya perceraian, tindak kekerasan dalam rumah tangga, tidak mendapatkan hak gono-gini, anak tidak diakui secara hukum, dll.

\section{Nikah Siri Dalam Perspektif Hukum Positif Indonesia ${ }^{16}$}

Undang-Undang (UU RI) tentang Perkawinan No. 1 tahun 1974 diundangundangkan pada tanggal 2 Januari 1974 dan diberlakukan bersamaan dengan dikeluarkannya peraturan pelaksanaan yaitu Peraturan Pemerintah No. 9 tahun 1975 tentang Pelaksanaan UU No. 1 tahun 1974 tentang Perkawinan. Menurut UU Perkawinan, perkawinan ialah ikatan lahir batin antara seorang pria dan seorang wanita sebagai suami istri dengan tujuan membentuk keluarga (rumah tangga) yang bahagia dan kekal berdasarkan Ketuhanan Yang Maha Esa (Pasal 1 UU Perkawinan). Mengenai sahnya perkawinan dan pencatatan perkawinan terdapat pada pasal 2 UU Perkawinan, yang berbunyi: “(1) Perkawinan adalah sah, apabila dilakukan menurut hukum masing-masing agamanya dan kepercayaannya itu; (2) Tiap-tiap perkawinan dicatat menurut peraturan perundang-undangan yang berlaku."

Dari Pasal 2 Ayat 1 ini, kita tahu bahwa sebuah perkawinan adalah sah apabila dilakukan menurut hukum masing-masing agamanya dan kepercayaannya itu. Ini berarti bahwa jika suatu perkawinan telah memenuhi syarat dan rukun nikah atau ijab kabul telah dilaksanakan (bagi umat Islam) atau pendeta/pastur telah melaksanakan pemberkatan atau ritual lainnya, maka perkawinan tersebut adalah sah terutama di mata agama dan kepercayaan masyarakat. Tetapi sahnya perkawinan ini

${ }^{16}$ http://www.google.com/Pernikahan-Siri-dari-Perspektif-Hukum-Indonesia.diakses pada tamggal 24 Oktober 2018 
di mata agama dan kepercayaan masyarakat perlu disahkan lagi oleh negara, yang dalam hal ini ketentuannya terdapat pada Pasal 2 Ayat 2 UU Perkawinan, tentang pencatatan perkawinan .Bagi mereka yang melakukan perkawinan menurut agama Islam pencatatan dilakukan di KUA untuk memperoleh Akta Nikah sebagai bukti dari adanya perkawinan tersebut. (pasal 7 ayat $1 \mathrm{KHI}$ "Perkawinan hanya dapat dibuktikan dengan Akta Nikah yang dibuat oleh Pegawai Pencatat Nikah"). Sedangkan bagi mereka yang beragama non muslim pencatatan dilakukan di kantor Catatan Sipil, untuk memperoleh Akta Perkawinan.

Mengenai pencatatan perkawinan, dijelaskan pada Bab II Pasal 2 PP No. 9 tahun 1975 tentang pencatatan perkawinan.Bagi mereka yang melakukan perkawinan menurut agama Islam, pencatatan dilakukan di KUA.Sedangkan untuk mencatatkan perkawinan dari mereka yang beragama dan kepercayaan selain Islam, cukup menggunakan dasar hukum Pasal 2 Ayat 2 PP No. 9 tahun 1975. Tata cara pencatatan perkawinan dilaksanakan sebagaimana ditentukan dalam Pasal 3 sampai dengan Pasal 9 PP No. 9 tahun 1975 ini, antara lain setiap orang yang akan melangsungkan perkawinan memberitahukan secara lisan atau tertulis rencana perkawinannya kepada pegawai pencatat di tempat perkawinan akan dilangsungkan, selambat-lambatnya 10 hari kerja sebelum perkawinan dilangsungkan. Kemudian pegawai pencatat meneliti apakah syarat-syarat perkawinan telah dipenuhi dan apakah tidak terdapat halangan perkawinan menurut UU. Lalu setelah dipenuhinya tata cara dan syarat-syarat pemberitahuan serta tidak ditemukan suatu halangan untuk perkawinan, pegawai pencatat mengumumkan dan menandatangani pengumuman tentang pemberitahuan kehendak melangsungkan perkawinan dengan cara menempel surat pengumuman pada suatu tempat yang sudah ditentukan dan mudah dibaca oleh umum.

Di dalam rancangan undang-undang menjelaskan, Pasal 143 RUU yang hanya diperuntukkan bagi pemeluk Islam ini menggariskan, setiap orang yang dengan sengaja melangsungkan perkawinan tidak di hadapan pejabat pencatat nikah dipidana dengan ancaman hukuman bervariasi, mulai dari enam bulan hingga tiga tahun dan denda mulai dari Rp 6 juta hingga Rp12 juta. Selain kawin siri, draf RUU juga menyinggung kawin mut'ah atau kawin kontrak.Dan Pasal 144 menyebut, setiap orang yang melakukan perkawinan mut'ah dihukum penjara selama-lamanya 3 tahun dan perkawinannya batal karena hukum.RUU itu juga mengatur soal perkawinan campur (antardua orang yang berbeda kewarganegaraan).Pasal 142 ayat 3 menyebutkan, calon suami yang berkewarganegaraan asing harus membayar uang jaminan kepada calon istri melalui bank syariah sebesar Rp500 juta.

\section{Simpulan}

Menurut hukum Islam, Nikah Siri siri adalah sah, asalkan telah terpenuhi syarat dan rukun perkawinannya. Namun dari aspek peraturan perundangan perkawinan model ini belum lengkap dikarenakan belum dicatatkan. Pencatatan 
perkawinan hanya merupakan perbuatan administratif yang tidak terpengaruh pada sah tidaknya perkawinan, sedangakan dalam perspektif Kristen merupakan pernikahan yang tidak dibenarkan oleh Al-kitab. Pernikahan Kristen yang sesungguhnya hanya diizinkan sekali seumur hidup kecuali diakibatkan oleh kematian. Dan menurut perspektif hukum positif Indonesia pernikahan siri melalui UU No. 1 tahun 1974 tentang Perkawinan menerangkan, (1) Perkawinan adalah sah, apabila dilakukan menurut hukum masing-masing agamanya dan kepercayaannya itu; (2) Tiap-tiap perkawinan dicatat menurut peraturan perundang-undangan yang berlaku. Dan Pasal 143 RUU menggariskan, setiap orang yang dengan sengaja melangsungkan perkawinan tidak di hadapan pejabat pencatat nikah dipidana dengan ancaman hukuman bervariasi, mulai dari enam bulan hingga tiga tahun dan denda mulai dari Rp 6 juta hingga Rp12 juta.Pernikahan dibawah tangan atau siri dapat disahkan dengan 2 (dua) cara yakni mengajukan istbat nikah atau dengan melakukan pernikahan ulang.

\section{Referensi}

Al-Zuhaili, Wahbah. Fiqh al-Islam wa 'Adillatuh, Juz VIII, Cet. III; Beirut: Dar alFikr, 1989.

Amin, Ma'ruf. dkk. Himpunan Fatwa Mui Sejak 1975, Jakarta: Erlangga, 2011.

Departemen Agama RI, Al-Qur"an al-Karim dan Terjemahnya, Semarang : CV. Toha Putra, 1996.

Geisler,Norman L. “Etika Kristen Pilihan dan Isu”. SAAT: Malang, 2010.

H.S.A Al Hamdani, Risalah Nikah, Hukum Perkawinan Islam, Jakarta :Pustaka Amani, 2002.

http://kampus.okezone.com/read/polemik-pernikahan-siri-perlindungan-hukum-bagiperempuan/

http://www.google.com/Pernikahan-Siri-dari-Perspektif-Hukum-Indonesia

J. Verkuil,“Etika Kristen Seksuil”. BPK: Jakarta, 1984

J.N.D Anderson, Hukum Islam di Dunia Modern. Yogyakarta: Tiara Wacana, 1994.

Latif, Nasarudin. Ilmu Perkawinan : Problematika Seputar Keluarga dan Rumah Tangga, Cet.1; Jakarta: Pustaka Hidayah, 2001.

Shihab, Quraish Wawasan al-Qur'an: Tafsir Maudhu'i Atas Perbagai Persoalan Umat, Cet. VIII; Jakarta: Mizan, 1998

Stott,John. “Isu-Isu Global Menantang Kepemimpinan Kristiani”, trans. G.M.A. Nainggolan. YKBK:Jakarta, 2005.

Sudarsono, Pokok-Pokok Hukum Islam, Cet.1; Jakarta: Rineka Cipta, 1992. 
Syarifuddin, Amir. Hukum Nikah Islam di Indonesia: Antara Fikih Munakahat dan Undang-Undang Nikah. Cet. II; Jakarta: Kencana, 2007.

Yunus, Mahmud. Hukum Perkawinan Dalam Islam Menurut Mazhab Syafi'I, Hanafi, Maliki dan Hanbali. Jakarta: Hidakarya Agung, 1996. 